\title{
ENCOURAGING AND LIMITING INVESTMENT FACTORS
}

\author{
Jugoslav Aničić, ${ }^{1}$ Vesna Petrović, ${ }^{2}$ Nataša Simić, ${ }^{3}$ Dušan Aničićc \\ University Union -Nikola Tesla, Faculty of Economics and Finance, Belgrade, Serbia \\ ajugoslav@yahoo.com

\section{Professional Paper 10.5937/jouproman8-25568}

\begin{abstract}
Investments are the basis for the growth and development of a company and for improving its competitiveness in the regional and international markets. Investment carries with it uncertainty and a high degree of risk since it is usually a long period of time from the moment of investment to the effects of return on investment. Therefore, an appropriate analysis of investment projects is required based on an assessment of the company's development capabilities. A number of factors, both internal and external, influence the successful realization of investment investments. Many of them cannot be operated by the company, and many other, unforeseen factors are emerging in a dynamic economic environment that can decisively affect the future business and survival of the company.
\end{abstract}

Keywords: investments, strategy, investment factors, company

\section{Introduction}

The ability of an enterprise to secure its growth and development on the basis of investments in the current conditions of a dynamic economic environment depends on the existing position on the market, financial strength, personnel structure and the accepted management concept. The efforts of the company to improve its position are manifested in the efforts to use the favorable challenge of future changes in the effect of certain factors. Therefore, the essence of investment planning is to investigate changes in external and internal factors that ultimately affect this process in terms of incentives or constraints.

Each of the phases of the life cycle of the company corresponds to a specific investment strategy. The analysis of development opportunities should provide the basis for choosing the appropriate investment strategy of the company. It is necessary because many factors, internal and external, place limits on the investment process. The investment process is a complex business activity of an enterprise, given the long-term nature of investment projects and the time gap between investment and investment effects. Also, the accompanying factors of each investment project is the great interdependence between investment and financing, as well as the risk and uncertainty of their realization.

\section{The importance of investment for enterprise development policy}

Investments are a concrete definition of the development policy of the company, so it is necessary to focus on the right ventures and ensure their realization. Investments are an important factor in the development of businesses, the economy and society as a whole. Business growth is often directly dependent on the volume of investments and their efficiency. Investing is a complex and dynamic process whose efficient progress is not possible without directing and leading to a defined goal. Formulating an investment strategy provides the company with ways to achieve its long-term development goals. 
Starting from the fact that through investments the company specifies the development policy, its efficiency will be determined by the ability to identify and make the best use of all environmental factors that can stimulate growth and development. The factors that encourage the future investment activity of a company are numerous and varied, so they can be classified in different ways, primarily depending on whether they are incentives of an internal or external nature.

The subject of investing may be different. An investment project should enable a rational investment decision to be made and is an instrument for implementing a growth strategy and business plan. The investment project encompasses and determines various analyzes and activities from the creation of the investment idea to its realization (Djuričin, Lončar, 2007).

The point of investing is to achieve certain effects, which may be different depending on the type of investment and the goals that you want to achieve. For a better understanding of investment effects, it is useful to classify investments that start from the following criteria: type of economic effects, object of investment and effect on the capacity of the enterprise (Ilić, 1979).

Dean (1951) points out that investments have many dimensions that can be viewed, inter alia, from the point of view of effects that are desired to be achieved such as cost reduction, increase of income, reduction of risk, improvement of position of employees, etc. From the point of view of strategic impact, investments do not have direct and immediate effects, but reflect the improvement of the overall competitiveness of the company.
The assessment of investment opportunities is often costly and requires large financial resources to gather information and analyze it. Successful investment projects depend directly on the creativity, enthusiasm, experience and judgment of the managers responsible for finding, defining and analyzing them (Pike, Dobins, 1987).

Depending on the type and type of investment decisions, the following characteristics are inherent in all projects of the company (Joksimović-Žarkić, et al, 2013):

- Long-term character of investment projects,

- Time gap between investment and investment effects,

- Interdependence between investment and financing,

- Risk and uncertainty.

\section{Investment incentives}

The environment is a unique, dynamic and complex strength that a company faces in the face of a variety of challenges, opportunities and threats. Environmental factors that stimulate the investment process can be driven by community measures, legislation, the development of science and technology, the development of sales and procurement markets, the position of the industry in the industry relative to competitors, the life cycle phase of the industry to which the enterprise belongs, as and the degree of development of the financial markets and its instruments (Todorović, et al, 1997). These are factors that cannot be controlled, but still have to be anticipated and anticipated in a timely manner in terms of influencing future business. 
In doing so, it is important to evaluate the speed of their occurrence, the certainty of their appearance and the length of their duration, because on the basis of this, the reaction of the company in the next planning cycle can be planned.

Social communities and legislation by incentive measures (such as reduced tax rates or other benefits) can act to increase investment. The achieved level of economic development, as well as the openness of the economy to other countries, can also significantly stimulate investment. The impact of science and technology is the fastest and most far-reaching in terms of creating favorable investment opportunities. Technological development creates opportunities for introducing new investment alternatives, through the possibility of creating new markets and changing the competitive position. The existence of financial markets is a factor that stimulates the investment process, because its functioning creates the opportunity for transparent and quick review and comparison of the rate of return on capital invested in companies in various branches of the economy. This works towards better allocation of financial and ultimately real resources in the domestic economy.

In addition to the above, other factors can be identified that serve as incentives for the firm's investment activity, but we will single out the firm's position in the industry relative to competitors and the life cycle phase of the industry in which the company competes (Hill and Jones, 1998).
The strength of a company's relative competitive position is determined by the following factors: the company's share of the market and the uniqueness, strength and number of distinctive competencies within the enterprise. The market share of a company is directly proportional to the return on investment. Specifically, the larger a firm's market share, the stronger its competitive position and the greater the potential returns from future investments.

Large market share provides businesses with economies of scale, such as cost reductions, both globally and nationally. Uniqueness, strength and number of distinctive competencies within the company is another measure of competitive position. Generally speaking, the two attributes reinforce each other, and at the same time explain why some businesses become stronger over time (Hill and Jones, 1998).

An important factor affecting attractiveness in terms of investment is the life cycle phase of an industry or industry. Each stage has different implications for investing resources in order to gain competitive advantage.

The authors G. Hill and G. Jones give an account of the relationship between the life cycle stage, competitive position and investment strategy at the business level, which can be seen in Figure 1. 


\begin{tabular}{|c|c|c|}
\hline $\begin{array}{c}\text { Industry life cycle } \\
\text { phase }\end{array}$ & Strong competitive position & Poor competitive position \\
\hline Embryonic Phase & $\begin{array}{c}\text { Market Share Building } \\
\text { Strategy }\end{array}$ & $\begin{array}{c}\text { Market Share Building } \\
\text { Strategy }\end{array}$ \\
\hline Growth phase & Growth strategy & $\begin{array}{c}\text { Market concentration } \\
\text { strategy }\end{array}$ \\
\hline Adaptation Phase & Market Share Increase & $\begin{array}{c}\text { Strategy Concentration of } \\
\text { market, or harvest/ liquidation }\end{array}$ \\
\hline Maturity stage & Maintenance or profit strategy & $\begin{array}{c}\text { Concentration Strategy, } \\
\text { harvest or liquidation }\end{array}$ \\
\hline Decline phase & $\begin{array}{l}\text { Strategy of market } \\
\text { concentration or harvest } \\
\text { (asset impairment) }\end{array}$ & $\begin{array}{c}\text { strategy turnaround, } \\
\text { liquidation or disinvestment } \\
\text { strategy }\end{array}$ \\
\hline
\end{tabular}

Figure 1. Choice of an investment strategy at any level of business (Hill and Jones, 1998, p. 205)

Each of these stages of the life cycle of an industry is matched by a specific investment strategy. Thus, in the embryonic phase, all businesses, regardless of their competitive position, place an emphasis on a strategy of building of market share, which automatically leads to high investment needs and considerable amounts of capital. In the growth phase, companies seek to maintain a relative competitive position in the market and, where possible, grow with the market. For companies with a strong competitive position, which are trying to increase their market share, an appropriate strategy at this stage is a growth strategy.

In the growth phase, companies make business-level investment decisions related to the relative benefits of differentiation strategy, low cost strategy or focus strategy, all relative to financial and relative needs and relative competitive position. Therefore, financial resources are needed that will be invested to develop new sales and marketing competencies. Companies with a weak competitive position at this stage, in order to keep pace with market growth or to consolidate their position, are implementing a market concentration strategy.

The aforementioned life cycle stages of the industry have different implications for the choice of investment alternatives that seek to gain a competitive advantage. Competition is strongest in the displacement phase and lowest in the embryonic phase. Conversely, investment needs are greatest in the embryonic phase, so it acts as an incentive for the investment process.

The intensity and effect of internal factors, as an incentive for investment, is based on the ability of a company to make the most of its internal strengths and powers, in order to achieve future growth. 
There are a number of internal parameters that affect the investment process, the impact of which is more or less dominant on the efficiency of the process. Although their weight and size are difficult to assess, the most significant ones are those related to the financial, resource (personnel, organizational and physical resources) and research and development capabilities of the enterprise.

One of the most important internal incentive factors for the investment process is the availability of financial resources, since the realization of the investment project chosen and acceptable by all criteria depends on them. The starting point for determining the required financial resources is the value of investing in the intended project. All projected investments must be covered by appropriate sources of funds.

In certain situations, investment can be driven by the availability of enterprise resources. They include experienced, capable and professional staff, organizational resources with an adaptable project organizational structure, and physical resources such as facility existence, favorable locations, distribution networks, etc.

The research and development capabilities of the company, which include the development of new products, the harmonization of the capacities of individual production units, the fuller utilization of certain raw materials, etc., can lead to the creation of a need for investment and opportunities for introduction of new investment alternatives for consideration.

In modern conditions, the range of factors affecting the investment process is broad and includes, in addition to the above, consideration of all other factors that determine the development behavior of companies, of which are of particular importance: the processes of internationalization of business and the use of merge and acquisition (external growth method) as a stimulus for growth (Cvetkovic, 2002).

A strong awareness of the challenges, factors and tendencies that come from the external environment have made the process of internationalization and globalization synonymous with the moment in which we live. This is not only the cause, but also the consequence of the intensive developing of various forms of international business cooperation through the increasing degree of interconnectedness of a wide range of participants in contemporary life. Under the influence of internationalization of business, through diversification of business activities and entry into foreign markets, the scope and structure of business activity of an enterprise increases, which is a direct incentive for its development behavior and investment. A prerequisite for rational choice of internationalization strategy and creation of mechanism for its implementation, it is necessary to evaluate as accurately as possible the attractiveness of individual markets, as well as the critical factors for efficient and effective business in them.

Nowadays, alliances of all kinds are increasingly common, especially in international business: joint ventures, minority shareholdings, cross-licensing and knowledge sharing arrangements. The reasons why businesses are guided in adopting this growth strategy are different. Many of them coincide with the reasons underlying the implementation of other growth strategies and therefore investment strategies. 
These trends (creating alliances of all kinds) tend to accelerate, primarily through mechanisms of exchange of ideas, experience and abilities. A "country and product strategy" is being developed. Attention is focused on optimal investment guidance across countries, businesses, products, market segments and business functions, in order to maximize profits. (Todorović, 1998, p. 168). In this way, through global thinking about markets and the possibilities of optimal allocation of resources, the investment process is stimulated and the development potential of the company is strengthened. The principle of openness to foreign capital makes it easier for developing countries to become part of the global space, with all the chances and dangers that exist there.

Merger or association, as a form of voluntary association of two companies, has long-term consequences, which affect its production and operational efficiency, size, market share, market position, etc. Through an increase in the overall level of efficiency, these strategies contribute to increasing the well-being of owners, business growth, entry into new markets, diversification, operational efficiency and profitability (Howe, 1988, pp. 170-174)

The analysis of internal development opportunities should help in choosing the right development strategy. Each strategic merger or merger alternative must be compared to internal alternatives, such as: internal growth and investment, joint ventures, creation of strategic alliances, technology licenses, etc. These alternatives should be compared on the basis of a number of criteria, in accordance with the set strategic goal of the company. In fact, companies that have recorded stable and significant growth are mostly aggressive, both in the field of mergers and acquisitions, as well as in the field of internal development.

\section{Limiting investment factors}

As the investment activity of the company is imbued with the interaction and effect of internal and external effects, their effect can be analyzed in the context of determining the incentive or limiting factors of investment. From the point of view of the investment process, the relationships between these factors, as well as the intensity of their impact, are of particular importance because it is through investments that development and development policy are realized.

Although the activity of individual incentives is aimed at initiating and stimulating investments, a number of limiting factors can counteract their effects. The theoretically observed enterprise can grow as long as it is able to find those strategies that will enable it to provide additional sources of profit. However, the reality is completely different, because there are a number of external and internal factors that represent limits to further investment, either slowing it down or eliminating it.

Among the many external factors that can act to limit or, in turn, eliminate the investment activity of an enterprise are the following:

- Declining market needs (declining sales and procurement markets);

- the existence of competition that creates large or even insurmountable barriers to entry into a

particular area of business; 
- the existence of almost insurmountable advantages of existing enterprises in the industry to

which they belong, starting with technological dominance, through the advantage of obtaining credit, and more favorable access to some inelastic distribution channels;

- legislation;

- reduced opportunities for procurement of material resources;

- limited or underdeveloped conditions for obtaining funding;

- underdevelopment of infrastructure;

- disincentives of the social community, that is, the country's economic policies (Todorović, et al, 1997).

All of these factors can, to a greater or lesser extent, represent limits to the investment process. The intensity of their action and the period of onset cannot be predicted. So, these are factors that are beyond the reach of anticipation of the company. Thus, for example, the economic policy of a country, by regulating the way in which businesses will conduct business, is a significant factor influencing the choice of investment strategy in terms of whether to invest or to resort to a strategy of disinvestment and abandonment. A restrictive investment policy will act to reduce investment. It is similar to the other factors listed above, each individually setting their own limits as a kind of constraint on the investment process.

Internal limits on investing result from the situation in the company and the growth so far. Although their number and impact are difficult to estimate, they are considered to be the most significant ones related to the financial, resource, personnel and $R \& D$ capabilities of the company. Lack of financial resources is one of the key factors limiting the whole investment process and especially comes to light when the investment activity takes place under conditions of large external and internal constraints. The lack of personnel potential in terms of number, experience, ability, knowledge, skill and reasoning of all employees in the company is certainly a factor limiting the investments and growth of the company. In addition, the lack of internal resources in the form of construction facilities, equipment, internal infrastructure and distribution network may also appear as a barrier to further investment. Specific limits may arise from the nature of the technological solution. With the increase of technical capacities, there are certain stages when the extra costs are higher than the costs of extra-designed capacities.

A number of other factors may, in turn, condition and limit the investment process. The company, therefore, has to shape the investment strategy in such a way that it matches its internal resources and capabilities.

\section{Conclusion}

Investment strategies are a basic way of realizing the goals of growth and development of a company, as well as maintaining and improving competitive advantage. The application of modern investment management methods enables the company to react quickly and adequately to the chances and threats from the environment, rationally use available resources and creates new projects and programs for their future business. The success of an investment project is affected by a number of internal and external factors, and many of them have no influence on the company. 
Investment therefore carries with it risk and uncertainty, since the time gap between investing and returning the effects of investing is often very long.All this requires that the investment process can be entered only on the basis of a serious analysis of the development capabilities of the company, bearing in mind the incentive and limiting factors for the success of that process.

\section{Literature}

Cvetković, N. (2002) Investment strategy of enterprises, Institute of Economic Sciences, Belgrade

Dean, J. (1951) Managerial Economics, PrenticeHall, New York

Djuricin, D., Loncar, D. (2007) Project Management, Faculty of Economics, Belgrade
Ilic, G. (1979) Long-term investments and the choice of sources of financing in OUR, Contemporary Administration, Belgrade

Hill, C., Jones, R. (1998) Strategic Management Theory - An Integrated Approach, Houghton Mifflin Company, Boston

Howe, W. (1988) Corporate Strategy, Macmillan, London

Pike, R., Dobbins, R. (1987) Investment Decisions and Financial Strategy, Philip Allan Publishers Limited, The Camelot Press, Southampton

Todorovic, J., Djuricin, D., Janosevic, S. (1997) Strategic Management, Institute for Market Research, Belgrade

Todorovic, J. (1998) Implications of Internationalization of Business on Company Strategy and Structure, Monograph: Challenges of Management and Marketing in a Global Environment, Belgrade

Zarkic-Joksimovic, N., Benkovic, S., Milosavljevic, M. (2013) Financial Management, Faculty of Organizational Sciences, Belgrade 